\title{
The impact of CO2-costs on biogas usage
}

\author{
Jensen, Ida Græsted; Nielsen, Lise Skovsgaard
}

Published in:

Energy

Link to article, DOI:

10.1016/j.energy.2017.06.019

Publication date:

2017

Document Version

Peer reviewed version

Link back to DTU Orbit

Citation (APA):

Jensen, I. G., \& Nielsen, L. S. (2017). The impact of $\mathrm{CO}_{2}$-costs on biogas usage. Energy, 134, 289-300. https://doi.org/10.1016/j.energy.2017.06.019

\section{General rights}

Copyright and moral rights for the publications made accessible in the public portal are retained by the authors and/or other copyright owners and it is a condition of accessing publications that users recognise and abide by the legal requirements associated with these rights.

- Users may download and print one copy of any publication from the public portal for the purpose of private study or research.

- You may not further distribute the material or use it for any profit-making activity or commercial gain

- You may freely distribute the URL identifying the publication in the public portal

If you believe that this document breaches copyright please contact us providing details, and we will remove access to the work immediately and investigate your claim 


\title{
The impact of $\mathrm{CO}_{2}$-costs on biogas usage
}

\author{
Ida Græsted Jensen ${ }^{\mathrm{a}, *}$, Lise Skovsgaard ${ }^{\mathrm{a}}$ \\ ${ }^{a}$ Technical University of Denmark, DTU Management Engineering, Produktionstorvet, Building 426, DK - 2800 \\ Kongens Lyngby, Denmark
}

\begin{abstract}
The Danish government has set a target of being fossil fuel independent by 2050 implying that a high degree of inflexible renewable energy will be included in the energy system; biogas can add flexibility and potentially has a negative $\mathrm{CO}_{2}$-emission. In this paper, we investigate the socioeconomic system costs of reaching a Danish biogas target of 3.8 PJ in the energy system, and how $\mathrm{CO}_{2}$-costs affect the system costs and biogas usage.

We perform our analysis using the energy systems model, Balmorel, and expand the model with a common target for raw biogas and upgraded biogas (biomethane). Raw biogas can be used directly in heat and power production, while biomethane has the same properties as natural gas. Balmorel is altered such that natural gas and biomethane can be used in the same technologies.

Several $\mathrm{CO}_{2}$-cost estimates are investigated; hereunder a high estimate for the expected $\mathrm{CO}_{2}$ externality costs. We find that system costs increase with $\mathrm{CO}_{2}$-costs in most cases, while the biogas target becomes socio-economically cheaper. In the case of a very high $\mathrm{CO}_{2}$-cost, system costs decrease and biomethane becomes the primary fuel. Furthermore, biomethane functions as regulating power and the Danish fuel consumption increases due to a higher electricity export.

Keywords: Energy systems modelling, Biogas, Biomethane, Renewable energy, Balmorel, $\mathrm{CO}_{2}$-externality costs
\end{abstract}

\section{Introduction}

The Danish climate strategy is shaped around a goal of being independent of fossil fuels in all energy consuming sectors by 2050, and one tool among many is biogas. First focus point have been the heat and power sector (from now on called the energy system) in which there has already

\footnotetext{
${ }^{*}$ Corresponding author: idje@dtu.dk
} 
been a large development in energy savings and implementation of renewable energy. Therefore, an energy system independent of fossil fuels by 2035 has been determined as a stepping stone towards the 2050 goal [1].

Biogas production have been developed in Denmark since the late 1970's with varying focus points [2]. Biogas is a renewable fuel that can be produced from a large variety of inputs such as manure, waste water and other wet substrates, which are expensive to use in other technologies. In Denmark, biogas is primarily based on manure of which there is an abundant supply from the large Danish agricultural industry. The degassed manure from the biogas process has an improved fertiliser value and can potentially improve the water environment as less nutrients are washed out from the fields. Furthermore emissions from the far more potent greenhouse gasses: methane $\left(\mathrm{CH}_{4}\right)$ and laughing gas $\left(\mathrm{N}_{2} \mathrm{O}\right)$ are converted into $\mathrm{CO}_{2}$-emissions - making biogas one of the few fuels that potentially can reduce greenhouse gas emission effects.

In Denmark, biogas has primarily been used in local, combined heat and power plants (CHPs). As biogas is produced constantly all over the year and it is expensive to store, it is also used constantly, i.e. producing a constant stream of heat and power. With an increase in volatile renewable power production, this is not necessarily the optimal usage of biogas. In 2014 new regulation was ratified, such that biogas is now also subsidised when it is upgraded to natural gas quality (biomethane). Biomethane can be transported in the natural gas grid, which allows it to be used where it is needed, when it is needed.

Biogas has been applied in other analyses on systems optimisation-in particular on the issue of waste as a fuel $[3,4,5]$. Biogas is often one fuel out of many and seldom turn out to be the preferred fuel as seen in e.g. [3] and the national biomass value chain model [6]. In our analysis, we turn our attention to biogas (hereunder biomethane) by including a separate target of biogas usage.

There is a variety of literature on energy systems optimisation using different optimisation models, e.g. Balmorel [7, 8, 9], MARKAL/TIMES [10, 11, 12], and EnergyPLAN [13, 14, 15]. An overview of existing energy systems models can be found in [16]. With the choice of model, it becomes necessary to assess whether the model can include varying properties of the two types of biogas and the target of biogas usage.

In this paper, we consider the year 2025 for which the Danish Energy Agency (DEA) has a 
prognosis of the biogas production [17], which seems to be aligned with the goal of being fossil fuel independent by 2035. We model biomethane as a substitute fuel for natural gas in an energy systems optimisation model and include a common goal on the use of biogas in the energy system. We allow the model to use biomethane as well as raw biogas and thereby we can compare the two options for the energy system. To our knowledge no other articles have included both raw biogas and biomethane in an energy systems optimisation model to evaluate their usage. The optimisation model is minimising the socio-economic cost of the energy system. From the model, the use of raw biogas and biomethane can be evaluated to find the socio-economic cost of a biogas target in the energy system both as a system cost and a marginal cost of the target. Furthermore, scenarios for different settings of the $\mathrm{CO}_{2}$-cost is introduced to evaluate the effect on the system cost and the marginal cost of the target.

\section{Biogas in Denmark}

Biogas production has been developed in Denmark since the late 1970s [2], primarily based on manure and co-substrates from a large agricultural industry; and due to regulation biogas plants have primarily supplied heat and power locally.

As Denmark moves towards being fossil independent by 2050, it becomes necessary to find replacements for particularly coal and natural gas in the energy system. There is already by 2017 a massive development in Denmark where coal to a large extent has been replaced by biomass and wind power. However, the lack of flexibility and predictability among renewable energy sources such as wind and solar power [18] has become a repeated concern, when renewable energy is integrated into the energy system. One suggested benefit from biogas is the potential to add this needed flexibility. The traditionally, Danish biogas usage where biogas is sent directly through a dedicated pipeline to a nearby CHP-plant, can however not be expected to add much flexibility —in some cases it might even work against flexibility, since an effective production of raw biogas only can vary a little and due to high costs with local storing [19] it has to be used gradually while it is produced.

Raw biogas can also be upgraded to natural gas quality and sent as biomethane into the national gas grid. Raw biogas is made of approximately $65 \%$ methane and $35 \% \mathrm{CO}_{2}$, and the upgrading process consists essentially in removing this $\mathrm{CO}_{2}$-surplus, converting the raw biogas 
into biomethane ( $98 \%$ methane and $2 \% \mathrm{CO}_{2}$ ). Alternatively, hydrogen from electrolysis could be added to raw biogas, converting the $\mathrm{CO}_{2}$-surplus into additional methane[20]. This process would increase the biomethane production with roughly $70 \%$. The biomethane can be transported in the gas grid, stored and used with the same flexibility as natural gas in the heat and power sector, in industry or in heavy transport.

\subsection{Biogas targets}

There is no particular target for Danish biogas usage in 2025. However, a target of using $50 \%$ of all manure for biogas production by 2020 was set in the Green Growth Agreement [21]. This is an extensive increase in the biogas production, as currently only $7-10 \%$ of the Danish manure is used for biogas production. If $50 \%$ of the manure were to be used for biogas production it would correspond to approximately $11 \mathrm{PJ}$.

The energy consumption prognosis from the Danish Energy Agency (DEA) [17], predicts a 7 PJ increase in total biogas consumption from 10 PJ in 2015 to 17 PJ in 2025. In figure 1 the latest and expected development in biogas consumption are depicted (left y-axis) and for comparison the natural gas consumption is also depicted (right y-axis). From this it is clear, that even with a high percentage increase in biogas consumption, it will still be far from the current natural gas consumption.

[Figure 1 about here.]

The latest calculations on future biogas potentials for Denmark corresponds to approximately 60-85 PJ [22, 23]. But even with such high production it only corresponds to roughly $10 \%$ of the current total energy demand in Denmark, which is around 750 PJ. Furthermore, biogas is considered relatively expensive compared to other renewable technologies. The expected Danish energy consumption is depicted in figure 2 together with the energy consumption for the energy system for 2015 and a prognosis for 2025 from the Danish Energy Agency (DEA).

[Figure 2 about here.]

From the 2025 prognosis it becomes clear that an increased biogas production is not expected to be used in the heat and power sector. An increase in biogas consumption is most likely to happen in the transport and industrial sectors according to the Danish biogas task force analysis [24]. 


\subsection{Regulation}

As already mentioned, support for biogas was until recently only given indirectly to electricity produced on raw biogas in a local CHP. With the new regulation support is also given to upgraded biogas. The support for 2015 can be seen in table 1 together with an approximation for the support in 2025. Since the support is dependent on both the natural gas price and the net price index, it is uncertain what the exact support will be in 2025 .

[Table 1 about here.]

With the current regulation, the support for raw and upgraded biogas is in many ways similar and since costs for upgrading are high, a private economic analysis could point to direct use as the preferred usage. According to [25], this is also the preferred choice as long as the plant is small. Following the inflexible production of biogas and the support design, when raw biogas is used in a local CHP, CHP is incentivised to produce constantly, independently of the electricity market. Support for biomethane is given before the biomethane is used and-except for a reduced $\mathrm{CO}_{2}{ }^{-}$ cost-biomethane is expected to have the same properties as natural gas and is taxed the same way. Therefore, the private economic competitiveness of biomethane can already be determined at the gate into the gas system: if the fuel costs including $\mathrm{CO}_{2}$-costs are sufficiently low, biomethane could compete with natural gas, which may favour upgrading [26, 27].

In conclusion, it is reasonable to expect that biogas will be used both raw and upgraded in the future energy system depending on the local conditions, e.g. the local district heating demand.

\section{Biogas in the energy system}

Based on the above, we find it reasonable to include both raw biogas and biomethane when we model biogas within a Danish energy system context. The raw biogas and biomethane should be included in the energy systems model with different properties, e.g. cost and efficiency, and the common target should be handled by the model.

\subsection{Balmorel}

We choose to use the energy system model, Balmorel [28], for analysing the use of raw biogas and biomethane. Balmorel is a bottom-up model in which the energy system can be optimised 
using an economic dispatch model, i.e. assuming all energy generating units are always online. The general economic dispatch model for electricity generation without investments can be written as:

$$
\begin{aligned}
& \text { Min. } z=\sum_{t \in \mathcal{T}} \sum_{a \in \mathcal{A}} \sum_{g \in \mathcal{G}} \sum_{s \in \mathcal{S}} \operatorname{cost}_{g} v g e_{a, g, s, t} \\
& \text { S.t. } \quad v g e_{g}^{\min } \leq v g e_{a, g, s, t} \leq v g e_{g}^{\max } \quad \forall a \in \mathcal{A}, g \in \mathcal{G}, s \in \mathcal{S}, t \in \mathcal{T} \\
& \sum_{g \in \mathcal{G}} v g e_{a, g, s, t}=d_{a, s, t} \quad \forall a \in \mathcal{A}, s \in \mathcal{S}, t \in \mathcal{T} \\
& \text { vge }_{a, g, s, t} \geq 0 \quad \forall a \in \mathcal{A}, g \in \mathcal{G}, s \in \mathcal{S}, t \in \mathcal{T}
\end{aligned}
$$

Line 1 is the total cost of producing on the installed technology type $g$. Here $\operatorname{cost}_{g}$ is the cost of producing one unit of power on technology $g$ and $v g e_{a, g, s, t}$ is the amount of electricity produced on technology $g$ in area $a$ in all time periods given by season $s$ and time $t$. Equation 2 ensures that each technology produces within its limits given by a minimum production limit, $v g e_{g}^{\min }$, and a maximum production limit, $v g e_{g}^{\max }$, in all areas and time periods. Equation 3 ensures that the electricity demand is met in all areas and time periods. Equation 4 ensures that the production is non-negative for all technologies in each area at all time periods. All used nomenclature can be seen in Appendix A. The economic dispatch problem can be extended to include heat-only technologies as well as combined heat and power technologies. This extension is not covered here, however, Balmorel includes both power and heat generation, as well as transmission within countries and between countries. The reader can refer to [28] for more details on modelling in Balmorel.

Balmorel is adoptable to any choice of geography, however it is used mostly in the Nordic and Baltic countries. Balmorel can be extended using several different add-ons, e.g. a unit commitment add-on, a policy add-on, and a time aggregation add-on. In this paper we use the economic dispatch model with optimisation of investments, and the combination technology add-on (Combtech) described in section 3.3 .

Balmorel performs an economic optimisation with a simplistic representation of a socio-economic analysis, which do not include all externalities. The socio-economic optimisation is a cost-based analysis, using neither national taxes nor subsidies, and costs used in the model are expected market prices. 


\subsection{Modelling of biogas in the energy system: limitations and delimitations}

Balmorel is run using economic dispatch, meaning that the fuel with the lowest cost for the system is used first and the most expensive fuels are used as regulating power. Given the inflexibilities of biogas production and expensive local storage [19], raw biogas cannot be used as regulating power in the system. This could be included in the model by forcing the model to use the raw biogas constantly. This addition would make the model an integer programming model and would increase running time significantly. With a long running time already before this addition, it is not considered a viable solution and the model is kept linear. Alternatively, the model could be forced to flare a certain percentage of the raw biogas. This, however, would require that the raw biogas is used as base load and, as described in section 6.2, the main investments for biogas are made in regulating power technologies. We therefore address this issue manually in the result analysis; and to avoid an extensive usage of raw biogas as regulating power - giving raw biogas an incorrect competitive advantage compared to biomethane - we do not allow the model to invest in new plants using raw biogas as fuel.

Aggregation is widely applied in Balmorel to make the model both faster and - as in the case of fuel usage - more specific. Time aggregation is applied by using a number of weeks during the year with a number of hours per weeks specified by the user. These choices will make the model faster than running the full year and - with a clever choice of weeks over the year - the results will be close to the full year model.

Fuel usage aggregation means that each technology has a specific fuel assigned to it with specific properties, hereunder efficiencies. One plant in the real world with different fuel inputs, would therefore be displayed in Balmorel as a number of technologies corresponding to the number of fuel inputs. Balmorel then optimises the fuel usage considering fuel costs, technology properties, capacity availability and so forth. At the same time, many plants in a given area are aggregated into one representative plant, meaning that in each area in Balmorel there can only be one plant of each technology.

A combined heat and power plant (CHP) using raw biogas cannot easily substitute the biogas with another fuel. A CHP using natural gas can however substitute the natural gas with biomethane, as this is essentially the same. 


\subsection{Combtech: combination of two technologies}

The relevant add-on for combining two technologies is called Combtech. To our knowledge, Combtech has only been used in one paper, [5], where it is used to evaluate how waste should be used in the energy system. Combtech can combine two technologies, a primary technology and a secondary technology, with similar characteristics, e.g. efficiencies, lifetime, and fuel type. In our case, the only characteristic biomethane and natural gas technologies do not share is the fuel type, which results in different $\mathrm{CO}_{2}$-emissions and fuel costs.

To allow substitution of fuels in a specific plant, the following constraints must be revised in Balmorel:

- Capacity constraints for existing and new energy conversion capacities

- Loss of electricity generation per unit of heat generated on extraction units for existing and new capacities

The capacity constraint is defined for existing electricity units, existing heat units, new electricity units, and new heat units. For the sake of simplicity, this constraint is only given for the existing electricity units but can easily be transferred to the other types by a name change in variables and sets. The existing electricity units $g$ are in the set $\mathcal{G}^{\text {elec, } 1}$ and $\mathcal{G}^{\text {elec,2}}$, where the first set is for the primary technologies and the second for secondary technologies. vge $e_{a, g, s, t}$ is the production of electricity in area $a$, on technology $g$, season $s$ and time $t$. The primary and secondary technologies are given from $g$ by $\mathcal{G}^{1}(g)$ and $\mathcal{G}^{2}(g)$, respectively. The capacity of technology $g$ in area $a$ is given by $c_{a, g}$ and the combination of areas and technologies where capacity exists is given by the set $\mathcal{A G K}$. The capacity constraint is:

$$
v e_{a, g, s, t}+\sum_{g_{2} \in \mathcal{G}^{2}(g)} v_{g e_{a, g_{2}, s, t}} \leq c_{a, g} \quad \forall a \in \mathcal{A}, g \in \mathcal{G}^{\text {elec }, 1},\{a, g\} \in \mathcal{A G K}, s \in \mathcal{S}, t \in \mathcal{T}
$$

Here the generation on the primary technology and all related secondary technologies are added and can not exceed the installed capacity.

An extraction unit can generate both heat and power, but in contrast to a back-pressure unit, the ratio between heat and power is not fixed. Instead the extraction unit will have a loss of electricity produced per unit of heat generated. The loss, which is given by the so-called Cv-line, is defined for both existing units and new units and is given here for the existing units. As for 
the capacity constraint, the constraint for the new units is similar and can be derived by a name change in variables and sets. The electricity loss of the extraction unit $g \in \mathcal{G}^{e x t, 1}$, is modelled using the parameter, $C_{g}^{v}$, which is assumed constant. The loss of electricity generation per unit of heat generated by extraction units is given by:

$$
\begin{aligned}
& v g e_{a, g, s, t}+\sum_{g_{2} \in \mathcal{G}^{2}(g)} v g e_{a, g_{2}, s, t} \leq c_{a, g}-C_{g}^{v} v g h_{a, g, s, t}-\sum_{g_{2} \in \mathcal{G}^{2}(g)} C_{g_{2}}^{v} v g h_{a, g_{2}, s, t} \\
& \forall a \in \mathcal{A}, g \in \mathcal{G}^{e x t, 1},\{a, g\} \in \mathcal{A G K}, s \in \mathcal{S}, t \in \mathcal{T}
\end{aligned}
$$

When optimising, Balmorel can then decide whether to use natural gas or biomethane in the production - taking fuel prices and restrictions into consideration.

\subsection{Modelling the biogas target}

The common biogas target for raw biogas and biomethane is included by a new constraint. The model is based on the abbreviations used above and the following is added. $\mathcal{A}(c)$ is the areas related to country $c . v g f_{a, g, s, t}$ is the used fuel in area $a$ on technology $g$ in season $s$ in time $t$ on installed capacity and $v g f n_{a, g, s, t}$ is the same for new capacity. $f u e l(g)$ is the fuel type used on technology $g$. The parameter called $G M I N 2 F_{c, f, f^{\prime}}$ is added to the model with the target described in section 4 and represents the target for fuel $f$ and $f^{\prime}$ in the country $c$. The target should be given in GJ.

The common target can be handled by the following constraint:

$$
\begin{aligned}
& 3.6 \cdot \sum_{a \in \mathcal{A}(c)}\left(\sum_{\substack{g \in \mathcal{G} \mid \\
f u e l(g)=f}} \sum_{s \in \mathcal{S}} \sum_{t \in \mathcal{T}}\left(v g f_{a, g, s, t}+v g f n_{a, g, s, t}\right)\right. \\
& \left.+\sum_{\substack{g \in \mathcal{G} \mid \\
f u e l(g)=f^{\prime}}} \sum_{s \in \mathcal{S}} \sum_{t \in \mathcal{T}}\left(v g f_{a, g, s, t}+v g f n_{a, g, s, t}\right)\right) \\
& \geq G M I N 2 F_{c, f, f^{\prime}} \quad \forall c \in \mathcal{C}, f \in \mathcal{F}, f^{\prime} \in \mathcal{F}
\end{aligned}
$$

The first line represents the amount of fuel type $f$ that is used and the second line represents the amount of fuel type $f^{\prime}$ used in the model. As the amount of fuel used is given in MWh and the target in GJ, the left hand side is multiplied by 3.6. Only the countries and fuels for which there are a specified target are bound by the constraint. 


\section{Assumptions and data}

For this analysis we simulate the Nordic countries and Northern Germany with a focus on Denmark, i.e. only a Danish target of biogas consumption. The countries are further divided on a regional level corresponding to the regions on Nordpool-except for Northern Germany, which is divided into three regions. The regions are further divided in up to 10 areas based on the demand, size and geography.

We model one year, 2025, using four full weeks, one in each season. Furthermore, we perform a simple socio-economic analysis, i.e. cost prices from a Danish viewpoint together with no taxes nor subsidies. $\mathrm{CO}_{2}$-emission is the only externality included in the optimisation and is represented by a socio-economic cost of $\mathrm{CO}_{2}$. Focus is on climate targets, as this is where biogas has a competitive advantage due to a negative $\mathrm{CO}_{2}$-emission in $\mathrm{CO}_{2}$-equivalents. This assumed negative emission is based on avoided methane and $\mathrm{N}_{2} \mathrm{O}$-emissions when manure is treated and thereby converted into biogas and digestate instead of being distributed directly on the fields. The $\mathrm{CO}_{2}$-emission value has been calculated by using the data from $[29,30]$.

[Table 2 about here.]

Fuel costs are mainly international market prices, following the assumption that most fuel prices will not be affected significantly by Danish fuel consumption. The primary source for fuel costs is the Danish Energy Agency (DEA) 2016-prognosis for socio-economic analysis, which is estimated on the basis of IEA prices [31]. The natural gas price is for example based on IEA prices adjusted to Danish price levels.

Fuels with high transportation costs, which do not enter the international markets, such as some biomasses, have an estimated cost which follows the closest substitute [31]. In the case of for example straw, the closest substitute is wood chips. Biogas costs are estimated on the basis of production costs found by using a profit optimising plant model with an input combination of manure and straw [27]. The straw price is the same as used in the energy systems analysis. The plant is large, using as input $600.000 \mathrm{t} / \mathrm{y}$ and generating a biogas yield of approximately $34 \mathrm{Mm} 3 / \mathrm{y}$. Costs are found both in relation to raw biogas and when upgrading costs for the biomethane are included. The upgrading to biomethane is done by water scrubbing.

Type of fuel cost method, fuel costs and $\mathrm{CO}_{2}$-emissions are listed in table 2. All costs are in $€ 2015$ prices. 


\subsection{The significance of price changes}

The Danish Energy Agency (DEA) assumes that fixed fuel prices will increase over the years, however, not extraordinarily [31]. There is a possibility that particularly biomass prices will increase more rapidly than expected, which could change the overall system results significantly. As we use the straw price as input to the biogas production, higher biomass prices will have an effect on the biogas costs and thereby an effect on the biogas target. However, higher biomass costs would improve the competitiveness of biogas compared to biomasses, as straw is a minor part of the biogas costs. The most important factor in relation to price changes is expected to be price changes for the nearest substitute, in this case natural gas.

\subsection{Targets and maximum consumption}

As mentioned in section 2.1 there are currently no biogas targets, so we set the biogas target following the biogas consumption prognosis for biogas in the heat and power sector from DEA [17], where biogas consumption in the energy system is expected to decline from $4.3 \mathrm{PJ}$ to approximately 3.8 PJ. This assumption follows the conclusions from the Biogas Taskforce as well as the general development in the Danish energy system, where natural gas based combined heat and power production is crowded out by primarily wind power [32].

[Table 3 about here.]

We do not use a target for natural gas consumption, however we set a limit following the DEA estimated use by 2025. In this estimation, it seems that the goal of a renewable founded heat and power production by 2035 is taken into account. Furthermore, there is a fixed usage of waste which is based on calculations using the FRIDA model [33] using the recycling targets from [34]. Last, an upper bound on wind potential is used, which is based on the IEA report [35].

\subsection{Production capacity}

We apply the existing generation capacity in the model by 2025, which for the Danish capacities are based on data from the Danish counting of energy production capacity by 2016 [36]. These capacities have been projected up to 2025 following expected remaining lifetimes and efficiencies. We allow the model to invest in further capacity in order to fill the gaps from existing, depreciated capacity and new demand. The given technology costs are found in the technology catalogues from 
DEA [37] and new investments are depreciated with a $4 \%$ interest rate following the instructions for socio-economic analysis in Denmark [38, 39]. Furthermore, it is assumed that all investments have a 20 year lifetime.

In table 4 the existing capacities for technologies using biogas are shown along with their average efficiencies.

\section{[Table 4 about here.]}

The model is allowed to invest in new capacity using natural gas/biomethane, but it is not allowed to invest in capacity using raw biogas. This is due to the challenges with raw biogas, where it is difficult to resemble reality and force the model to use the same amount of biogas all over the year, as explained in section 3.3. As it turns out, this will only be an issue in one scenario.

\section{Scenarios}

In order to understand the socio-economic costs from setting a target for biogas usage in the Danish Energy System, two primary scenarios are considered. A Base-scenario with no biogas target and a Target-scenario, with a target for biogas. A determining factor for the result is the socio-economic cost of $\mathrm{CO}_{2}$. When the socio-economic cost of $\mathrm{CO}_{2}$ is high, fossil fuels becomes relatively less competitive. In the case of biogas, this becomes even more relevant, as biogas is assumed to have a negative $\mathrm{CO}_{2}$-emission. Therefore three secondary scenarios are added investigating the importance of the $\mathrm{CO}_{2}$-cost. The settings used can be seen in table 5 .

[Table 5 about here.]

[Figure 3 about here.]

In figure 3, the $\mathrm{CO}_{2}$-cost is added to the fuel cost to illustrate the significance of the $\mathrm{CO}_{2}$-cost. It becomes clear that the closest substitute to biogas, natural gas, continue to be cheaper than biogas - even in the high $\mathrm{CO}_{2}$-cost scenario, given the expected development in natural gas prices.

The actual socio-economic cost of $\mathrm{CO}_{2}$-emissions from the Danish energy production is difficult to estimate correctly. Therefore, we followed the recommendation from DEA [31] to use different prognoses for the $\mathrm{CO}_{2}$-quota price, assuming, that this to some extent corresponds to the socioeconomic cost. We used the DEA 2015-prognosis for the high and low $\mathrm{CO}_{2}$-quota price which is 
based on current $\mathrm{CO}_{2}$-quota prices and the IEA World Economic outlook prognosis from 2015. Finally, we used the average of the two scenarios. All scenarios are shown in table 5.

\section{1. $\mathrm{CO}_{2}$-externality cost scenarios}

The European $\mathrm{CO}_{2}$-quota prices are based on the expected marginal costs of $\mathrm{CO}_{2}$-emission reduction given the political decided cap on $\mathrm{CO}_{2}$-emissions within the $\mathrm{CO}_{2}$-quota affected sectors. As the cap is politically decided it is not necessarily related to any expectations for the actual $\mathrm{CO}_{2}$-externality costs, and compared to the literature, these costs also seem rather low. In [40] several estimations for the $\mathrm{CO}_{2}$-externality costs from the literature are collected and evaluated, and from this a lower bound for the social cost of $\mathrm{CO}_{2}$ is formed. This bound is high compared to other cost estimates in the literature [40].

To see what happens to the biogas consumption when a higher $\mathrm{CO}_{2}$-cost is used in the model, we include this lower bound as the Van den Bergh $\mathrm{CO}_{2}$-cost in the CO2Bergh/Target scenario. Further, we use the lower estimate from [41] in the CO2Dice/Target scenario to compare the results from the DEA estimates on marginal $\mathrm{CO}_{2}$-emission reduction costs to the estimated $\mathrm{CO}_{2}$ externality costs from [40] and [41]. The used $\mathrm{CO}_{2}$-costs and the resulting fuel costs for natural gas, biomethane, and biogas can be seen in table 6 for the scenarios with high $\mathrm{CO}_{2}$-cost.

[Table 6 about here.]

It is noticeable that the Dice $\mathrm{CO}_{2}$-externality costs are quite close to the estimated high $\mathrm{CO}_{2}$ quota price from the DEA.

\section{Results}

Seven scenarios have been run: two primary and three secondary, as well as two sensitivity analysis scenarios of the $\mathrm{CO}_{2}$-costs.

\subsection{System cost}

Five parameters are presented in Table 7 giving the overall results from the scenario runs. The objective function value, OBJ, constitute the total system costs of the given scenario in Million Euro. Whereas $\triangle$ OBJ shows the additional system cost of a scenario in relation to the base scenario. The system cost increases when a biogas target is added, as the model would otherwise 
have used the biogas already. However, the results show, that the system cost increase is low, compared to a high $\mathrm{CO}_{2}$-cost. This makes sense as biogas corresponds to approximately $1.6 \%$ of the fuel usage in the target scenario while fossil fuel usage corresponds to approximately $36 \%$ of the fuel usage in all scenarios. Furthermore, we find that it becomes relatively less costly to add a biogas target as the $\mathrm{CO}_{2}$-cost increases, which is due to the negative $\mathrm{CO}_{2}$-emissions from biogas.

[Table 7 about here.]

The marginal cost of forcing a biogas target of 3.8PJ on the system is between $1.23-3.36 € /$ GJ depending on the $\mathrm{CO}_{2}$-cost. In order to make biogas socio-economically worthwhile, the actual $\mathrm{CO}_{2}$-externality cost should prove to be even higher in order to call the biogas target socio-economic beneficial. Alternatively, other benefits from biogas production could be considered, such as positive externalities from e.g. reduced smell, increased quality of agricultural fertilisers, possible reduced nutrient releases to groundwater, or job creation in rural areas.

The last parameters, $\mathrm{CO}_{2}$-total and $\mathrm{CO}_{2}$ - $\mathrm{DK}$, show the amount of $\mathrm{CO}_{2}$-emissions for the scenarios. Here it shows that a biogas target changes the $\mathrm{CO}_{2}$-emissions in Denmark more than the high $\mathrm{CO}_{2}$-cost. The Danish biogas target has an effect on the total $\mathrm{CO}_{2}$-emission. This can be seen by the total $\mathrm{CO}_{2}$-emission in the target scenarios being reduced more than the Danish $\mathrm{CO}_{2}$-emissions and can be explained by an increase of electricity transmission to Germany, which reduces the use of coal in Germany and therefore a decrease in the $\mathrm{CO}_{2}$-emissions.

\subsection{Fuel and capacity usage}

In table 8 it shows that the upper bound on natural gas usage is binding through all the scenarios. In all scenarios, however, only approximately $11-12 \%$ of the installed capacity is used, and only a small fraction of the used capacity is using biomethane. An explanation of this low usage combined with new investments could be that gas primarily is used for regulating power. This is substantiated by $80-98 \%$ of the new investments in combination technologies are in power producing capacity. Both raw biogas and biomethane are used in the target-scenarios, however, raw biogas is preferred to biomethane due to the lower fuel costs. The model does not distinguish between raw biogas and combination technologies as we have not included the problems with flexible usage of raw biogas in the model, see section 3.2. These observations emphasise the need of not allowing the model to invest in new capacity using raw biogas. 
[Table 8 about here.]

[Figure 4 about here.]

Figure 4 displays the normalised fuel usage in the base and target scenarios in order to compare how fuel consumption differs. As the biogas target represent a small share of the total energy consumption it is no surprise, that the overall fuel consumption is quite similar. However, it can be seen that the additional biogas usage is substituting use of oil and heat pumps, but also biomass.

[Figure 5 about here.]

Figure 5 presents the three target scenarios and displays the significance of the $\mathrm{CO}_{2}$-costs on fuel usage. The figure shows, that the usage of coal, natural gas, waste, wind, and sun does not change through the scenarios. Relating this to figure 3, an explaining factor can be that neither coal, natural gas nor waste changes position in the ranking of fuel costs with these changes in the $\mathrm{CO}_{2}$-costs. When the $\mathrm{CO}_{2}$-cost is low, it is preferred to use heat pumps, oil, and surplus heat in the system, whereas biomass and biogas is preferred when the $\mathrm{CO}_{2}$-cost is high.

For the CO2Low/Target scenario, the usage of biomethane is higher than in any other scenario. This is due to the fact that when comparing raw biogas and biomethane, the fuel costs become relatively closer to each other when the $\mathrm{CO}_{2}$-cost is low compared to when the $\mathrm{CO}_{2}$-cost is high . Biomethane is still more expensive, but when the costs are relatively closer, other factors become more determining for the result. These factors are e.g. technology efficiency, investment and operational costs, and the relative demand between heat and power.

Waste, wind, and sun are used equally across all scenarios. This is due to the fact that the maximum restrictions on these energy sources are binding in all scenarios. It is out of the scope of this paper to evaluate further on the restrictions. The results, however, indicate that the restrictions have an influence on the final results.

\subsection{Usage of raw biogas in the system}

Raw biogas is preferred to biomethane in all scenarios due to the lower fuel costs of raw biogas while not all inefficiencies from the real world are implemented in the model, as e.g. the need for an almost constant use of raw biogas. Figure 6 represents the usage of raw biogas in the CO2High/Target scenario, where the biogas usage in GJ for CHP-units relates to the right y-axis 
and boilers plus electricity-only units relates to the right y-axis. It is clear, that raw biogas primarily is used in CHP-units and mostly during winter and autumn (first and last period) and as regulating power during spring and summer. If a real world biogas based CHP had this consumption pattern, it would result in approximately $30 \%$ of the gas being flared, which would increase the cost of using raw biogas considerably. More likely, the plant would produce constantly, thus decreasing the value of the output for the system and thereby also the value of the raw biogas.

[Figure 6 about here.]

\subsection{When the $\mathrm{CO}_{2}$-externality costs are implemented}

While the first scenarios presented in this paper relate to estimated $\mathrm{CO}_{2}$-cost from a $\mathrm{CO}_{2}$ quota system, the $\mathrm{CO}_{2}$-costs in the last two scenarios are related to estimations of the actual $\mathrm{CO}_{2}$-damage costs: a low and a high estimate. As given in table 6 , the estimated $\mathrm{CO}_{2}$-costs in the CO2Dice/Target scenario are quite close to CO2High/Target scenario, which is also reflected in the result summary in table 9. However, the interpretation of the costs is not the same. Total system costs increase slightly from the CO2High/Target to the CO2Dice/Target scenario, while the marginal costs of having a target for biogas usage approaches zero, so it seems that the $\mathrm{CO}_{2}$-costs approaches a breaking point where the needed biogas would be used without a target.

[Table 9 about here.]

Total system costs are low in the CO2Bergh/Target scenario compared to the other high $\mathrm{CO}_{2}-$ cost scenarios. This decrease in system costs is based on fuel costs of raw biogas and biomethane, which are low due to their negative $\mathrm{CO}_{2}$-emission. This also result in a high use of biomethane, which by far exceeds the target and thereby reduces the marginal cost of the biogas target to zero.

[Figure 7 about here.]

In table 9 we see a small decrease in both usage and installation of combination technologies in the CO2Dice/Target scenario, and in figure 7, we see that biomass seems to have become relatively more attractive in the CO2Dice/Target scenario. In the CO2Bergh/Target scenario on the other hand, both the degree of capacity usage and investments increase, which could also be expected considering the increased usage of biomethane - reflected in figure 7 . 
The $\mathrm{CO}_{2}$-emissions show to be negative for both Denmark and the total energy system for the $\mathrm{CO} 2 \mathrm{Bergh} /$ Target scenario as shown in table 9. The negative $\mathrm{CO}_{2}$-emission in Denmark is explained by the excessive usage of biomethane in Denmark as shown in figure 7. For the total system, the important contributor to negative $\mathrm{CO}_{2}$-emissions is Germany where biomethane is also used to a large extent-resulting in negative $\mathrm{CO}_{2}$-emissions for the whole system.

The accumulated amount of fuels used in the CO2Bergh/Target scenario exceeds the fuel usage in any of the other scenarios. This can be explained by electricity based on biomethane becoming cheap enough to substitute a large amount of electricity production in Germany, resulting in an increased electricity export and a higher fuel usage in Denmark.

The natural gas consumption in this scenario has been replaced completely with biomethane, which then function as a base load provider during winter and autumn, and provider of regulating power during the summer period. This underlines, that biomethane can indeed function as a fuel for regulating power, using the gas transmission net as energy storage - in a scenario where $\mathrm{CO}_{2}$-costs are very high.

The suggested biomethane consumption in CO2Bergh/Target scenario exceeds by far the sketched biogas potential in section 2.1, which means that more biogas would have to be produced. This could be through the addition of imported biomasses or e.g. grown algaes, which are not considered in the current prognosis for biogas potentials[22, 23]. Furthermore, biogas could be upgraded by methanation where hydrogen is added to the raw biogas, such that excess $\mathrm{CO}_{2}$ and hydrogen are converted into $\mathrm{CH}_{4}$ and thereby increase the biomethane production by approximately $70 \%$ [42]. The hydrogen could be produced when electricity prices are low. Potentially, this can help even-out the electricity price and give an effective way to store electricity when there is an oversupply. How the additional biomethane is produced and interacts with the energy system is out of scope of this paper. It can, however, be expected that biomethane made by methanation will affect the assumed $\mathrm{CO}_{2}$-emission related to biomethane such that less $\mathrm{CO}_{2}$ will be reduced per GJ biomethane produced. When fed into the calculation, this should make the model less eager to use the large amount of biomethane. 


\section{Conclusion}

In this paper we investigated the socio economic system costs of having a biogas target in Denmark, and how $\mathrm{CO}_{2}$-costs affect the system costs and biogas usage. To do this, we used the energy system model Balmorel with the possibility to combine natural gas with biomethane in one technology. Furthermore, we set a target for raw biogas and biomethane corresponding to the predicted amount used in the heat and power sector in 2025. First, the model was applied using predictions of $\mathrm{CO}_{2}$-costs from the Danish Energy Association. Then, we added two sensitivity analysis scenarios where we applied higher $\mathrm{CO}_{2}$-costs corresponding to estimates for the actual $\mathrm{CO}_{2}$-externality costs found in the literature.

From our analysis, we see that we need a very high $\mathrm{CO}_{2}$-cost estimate in the area of the $\mathrm{CO}_{2}$ costs estimated by Van den Bergh [40] before biogas or biomethane is worthwhile using in large amounts. When increasing the $\mathrm{CO}_{2}$-costs, the biogas target becomes less costly while the total system cost increases. First when $\mathrm{CO}_{2}$-costs are very high, biogas becomes worthwhile and used to such an extent, that total system costs decline. Even though the very high $\mathrm{CO}_{2}$-cost might not be justified, there could still be arguments for forcing the system to use biogas, as there are other positive externalities from biogas than $\mathrm{CO}_{2}$-reductions. This has, however, not been investigated further in this paper.

There are investments in combination technologies in all scenarios, but the usage of the natural gas technologies is relatively low, and the existing combination technologies are not used much. This suggests that gas primarily is used as regulating power. However, with very high $\mathrm{CO}_{2}$-costs, combination technologies are used as base-load during winter and regulating power during summer. Furthermore, there is an increase in export of electricity in this scenario, which can be explained by the fact that the high $\mathrm{CO}_{2}$-cost reduces the biomethane cost, and thereby increases biomethane's competitiveness compared to other electricity sources in the surrounding countries.

The scenario with the $\mathrm{CO}_{2}$-cost estimate by [40] leads to an extensive usage of biogas that exceeds the potentials described in [22]. The lack of biogas resources could partly be overcome by biogas upgrading through methanation where hydrogen is used to upgrade the biogas. This could be investigated further in an energy system where the upgrading of biogas is included. This requires new estimates of the biogas $\mathrm{CO}_{2}$-emissions, since upgraded biogas through methanation contains a lower share of manure per GJ and thereby also another level of $\mathrm{CO}_{2}$-emissions. 


\section{Acknowledgement}

This article is part of the project "Optimisation of value chains for biogas production in Denmark (BioChain)" funded by the Danish Council for Strategic Research (DSF), under the "Strategic Research in Sustainable Energy and Environment" research programme (Grant number: 12132631). The authors are responsible for the content of this publication.

\section{References}

[1] Danish Energy Agency, Energiscenarier frem mod 2020, 2035 og 2050 (Energy scenarios towards 2020, 2035, and 2050) (2014). doi: ISBN: 978-87-93071-64-3.

URL https://ens.dk/sites/ens.dk/files/EnergiKlimapolitik/energiscenarier___analyse_2014_web.pdf

[2] R. Lybæk, T. B. Christensen, T. Kjær, Governing innovation for sustainable development in the danish biogas sector - a historical overview and analysis of innovation, Sustainable Development (2013) 171-182doi:10.1002/ sd.1548.

[3] M. Münster, H. Lund, Use of waste for heat, electricity and transport-Challenges when performing energy system analysis, Energy 34 (5) (2009) 636-644. doi:10.1016/j.energy.2008.09.001.

[4] M. Münster, P. Meibom, Long-term affected energy production of waste to energy technologies identified by use of energy system analysis, Waste Management 30 (12) (2010) 2510-2519. doi:10.1016/j.wasman.2010.04.015.

[5] M. Münster, P. Meibom, Optimization of use of waste in the future energy system, Energy 36 (3) (2011) 1612-1622. doi:10.1016/j.energy.2010.12.070.

[6] S. Samsatli, N. J. Samsatli, N. Shah, BVCM: A comprehensive and flexible toolkit for whole system biomass value chain analysis and optimisation - Mathematical formulation, Applied Energy 147 (2015) 131-160. doi: 10.1016/j.apenergy.2015.01.078.

[7] K. Karlsson, P. Meibom, Optimal investment paths for future renewable based energy systems-Using the optimisation model Balmorel, International Journal of Hydrogen Energy 33 (7) (2008) 1777-1787. doi:10.1016/ j.ijhydene.2008.01.031.

[8] L. Kitzing, H. Ravn, Support mechanisms and risk: Implications on the Nordic electricity system, in: 2013 10th International Conference on the European Energy Market (EEM), IEEE, 2013, pp. 1-7. doi:10.1109/ EEM.2013.6607341.

[9] K. Hedegaard, O. Balyk, Energy system investment model incorporating heat pumps with thermal storage in buildings and buffer tanks, Energy 63 (2013) 356-365. doi:10.1016/j.energy.2013.09.061.

[10] K. Q. Nguyen, Impacts of wind power generation and CO2 emission constraints on the future choice of fuels and technologies in the power sector of Vietnam, Energy Policy 35 (4) (2007) 2305-2312. doi: 10.1016/j.enpol.2006.06.023.

[11] K. Vaillancourt, M. Labriet, R. Loulou, J. P. Waaub, The role of nuclear energy in long-term climate scenarios: An analysis with the World-TIMES model, Energy Policy 36 (7) (2008) 2296-2307. doi:10.1016/ j.enpol.2008.01.015. 
[12] A. Elobeid, S. Tokgoz, R. Dodder, T. Johnson, O. Kaplan, L. Kurkalova, S. Secchi, Integration of agricultural and energy system models for biofuel assessment, Environmental Modelling \& Software 48 (2013) 1-16. doi: 10.1016/j.envsoft.2013.05.007.

[13] K. Hedegaard, B. V. Mathiesen, H. Lund, P. Heiselberg, Wind power integration using individual heat pumps - Analysis of different heat storage options, Energy 47 (1) (2012) 284-293. doi:10.1016/j.energy.2012.09.030.

[14] P. S. Kwon, P. A. Østergaard, Priority order in using biomass resources - Energy systems analyses of future scenarios for Denmark, Energy 63 (2013) 86-94. doi:10.1016/j.energy.2013.10.005.

[15] D. A. Hagos, A. Gebremedhin, T. Folsland Bolkesjø, Comparing the value of bioenergy in the heating and transport sectors of an electricity-intensive energy system in Norway, Energy Policy 85 (2015) 386-396. doi: 10.1016/j.enpol.2015.06.021.

[16] D. Connolly, H. Lund, B. V. Mathiesen, M. Leahy, A review of computer tools for analysing the integration of renewable energy into various energy systems, Applied Energy 87 (4) (2010) 1059-1082. doi:10.1016/ j.apenergy.2009.09.026.

[17] Danish Energy Agency, Baseline Projections from DEA.

URL https://ens.dk/en/our-services/projections-and-models/danish-climate-and-energy-outlook

[18] International Energy Agency, Empowering Variable Renewables - Options for Flexible Electricity Systems, OECD/IEA.

URL https : / / www.iea.org / publications / freepublications / publication / Empowering_Variable_Renewables.pdf

[19] NIRAS, Biogas drifts- og samfundsøkonomisk analyse (Biogas private and socioeconomic analysis) (2010).

URL http://energinet.dk/SiteCollectionDocuments/Danske\%20dokumenter/Gas/Biogas $\% 20 \mathrm{drifts}-\% 20$ og\% 20samfunds $\%$ C3 $\%$ B 8 nokomisk $\% 20$ analyse $\% 20-\% 20$ S $\%$ C3 $\%$ A6sonvariation.pdf

[20] L. Jürgensen, E. A. Ehimen, J. Born, J. B. Holm-Nielsen, Utilization of surplus electricity from wind power for dynamic biogas upgrading: Northern Germany case study, Biomass and Bioenergy (2014) 126-132doi: 10.1016/j.biombioe.2014.02.032.

[21] Danish Government, Aftale om Grøn Vækst (Green Growth Agreement) (2009). URL https://www.danskfolkeparti.dk/pictures_org/Grn\%20Vkst-aftale_final.pdf

[22] T. Birkmose, K. Hjort-Gregersen, K. Stefanek, Biomasse til biogasanlæg i Danmark - på kort og langt sigt (Biomass to biogas plants on the long and short term), Tech. Rep. april (2013).

URL https://ens.dk/sites/ens.dk/files/Bioenergi/biomasser_til_biogasanlaeg.pdf

[23] EA Energi Analyses, Anvendelse af biogas til el- og varmeproduktion (Usage of biogas to electricity and heat production), Tech. rep. (2014).

URL https://ens.dk/sites/ens.dk/files/Bioenergi/anvendelse_af_biogas_til_el_og_varme_2.pdf

[24] Danish Energy Agency, Biogas i Danmark--status, barrierer og perspektiver (Biogas in Denmark-status, barriers, and perspectives), Tech. rep. (2014).

URL https://ens.dk/sites/ens.dk/files/Bioenergi/biogas_i_danmark_-_analyse_2014-final.pdf

[25] M. Pöschl, S. Ward, P. Owende, Evaluation of energy efficiency of various biogas production and utilization pathways, Applied Energy 87 (11) (2010) 3305-3321. doi:10.1016/j.apenergy.2010.05.011. 
[26] L. Skovsgaard, H. K. Jacobsen, Economies of scale in biogas production and the significance of flexible regulation, Energy Policy 101 (2017) 77-89. doi:10.1016/j.enpol.2016.11.021.

[27] I. G. Jensen, M. Münster, D. Pisinger, Optimizing the supply chain of biomass and biogas for a single plant considering mass and energy losses, European Journal of Operational Research (2017) -doi:https://doi.org/ 10.1016/j.ejor.2017.03.071.

[28] H. Ravn, M. Hindsberger, R. Schmidt, R. Bøg, P. E. Grohnheit, M. Petersen, H. V. Larsen, J. Munksgaard, J. Ramskov, M.-R. Esop, G. Klavs, A. Galinis, R. Paprocki, M. Wawrzyszczuk, A. Gloukhov, Balmorel: A model for analyses of the electricity and CHP markets in the Baltic Sea Region, ElkraftSystem, 2001.

URL http: / / eabalmorel.dk/files/download/Balmorel \% 20A \% 20Model \% 20 for \% 20Analyses \% 20of \% 20the \% 20Electricity $\% 20$ and $\% 20$ CHP $\% 20$ Markets $\% 20$ in $\% 20$ the $\% 20$ Baltic $\% 20$ Sea $\% 20$ Region.pdf

[29] H. Wenzel, L. Høibye, R. Duban Grandal, L. Hamelin, D. N. Bird, A. Olesen, Carbon footprint of bioenergy pathways for the future Danish energy system, Tech. Rep. March (2014).

URL https://ens.dk/sites/ens.dk/files/Bioenergi/carbon_footprint_of_bioeneergy_pathways_for_the_future_danish_e _final_210314_1.pdf

[30] H. Wenzel, L. Hamelin, Identifying marginal biomass supply and its carbon footprint under varying future framework conditions (2015).

URL http : / / www.sdu.dk / - / media / files / om_sdu / centre / lifecycleengineering / reports / wenzel_et_al_2015_global_biomass_marginals.pdf

[31] Danish Energy Agency, Forudsætninger for samfundsøkonomiske analyser på energiområdet (Assumptions for socio-economic analyses within energy) (april) (2016) 1-22.

URL https://ens.dk/sites/ens.dk/files/Analyser/samfundsoekonomiske_beregningsforudsaetninger_2016_v3.pdf

[32] EA Energy Analyses, Afsætning af biogas til industri (Industrial purchase of biogas), Tech. rep. (2014). URL https://ens.dk/sites/ens.dk/files/Bioenergi/afsaetning_af_biogas_til_industri_-_final.pdf

[33] F. M. Andersen, H. V. Larsen, FRIDA: A model for the generation and handling of solid waste in Denmark, Resources, Conservation and Recycling 65 (2012) 47-56. doi:10.1016/j.resconrec.2012.04.004.

[34] A. L. Hill, O. L. Dall, F. M. Andersen, Modelling Recycling Targets : Achieving a $50 \%$ Recycling Rate for Household Waste in Denmark, Journal of Environmental Protection (May) (2014) 627-636. doi:10.4236/ jep.2014.57064.

[35] IEA, Nordic Energy Technology Perspectives 2016doi:10.1787/9789264257665-en.

[36] Danish Energy Agency, Energiproducenttællingen (Energy producer count) (2016).

[37] Danish Energy Agency, Technology data for energy plants, no. August, 2016. URL https://ens.dk/sites/ens.dk/files/Analyser/teknologikatalog_august_2016_08082016.pdf

[38] Danish Energy Agency, Vejledning i samfundsøkonomiske analyser på energiområdet (Guidance for socioeconomic analyses within energy), Tech. Rep. April 2005, rev. 2007 (2005).

URL https://ens.dk/sites/ens.dk/files/Analyser/vejledning_2005-rev2007.pdf

[39] Danish Energy Agency, Opdateret tillægsblad om kalkulationsrente, levetid og reference (Updated sheet on calculation rate, life time, and reference) (2013).

URL https://ens.dk/sites/ens.dk/files/Analyser/notat_om_kalkulationsrenten_juni_2013.pdf 
[40] J. C. J. M. van den Bergh, W. J. W. Botzen, A lower bound to the social cost of CO2 emissions, Nature Climate Change 4 (4) (2014) 253-258. doi:10.1038/nclimate2135.

[41] A. L. Marten, S. C. Newbold, Estimating the social cost of non-CO2 GHG emissions: Methane and nitrous oxide, Energy Policy 51 (2012) 957-972. doi:10.1016/j.enpol.2012.09.073.

[42] A. Evald, G. Hu, M. T. Hansen, Technology data for advanced bioenergy fuels, Tech. rep. (2013). URL https://ens.dk/sites/ens.dk/files/Analyser/1_teknologikatalog_for_konvertering_af_biomasse_til_biobraendsle 


\section{Appendix A. Nomenclature}

\section{Sets}

$\mathcal{A G K}$ Combination of areas and technologies where capacity exists

$\mathcal{A}(c)$ All areas in country $c$

$\mathcal{A}$ All areas

$\mathcal{G}^{2}(g)$ Secondary technologies for primary technology
$\mathcal{G}^{\text {elec,1}}$ Primary technologies producing electricity $\mathcal{G}^{\text {ext,1}}$ Primary technologies that are extraction units $\mathcal{S}$ All seasons

$\mathcal{T}$ All time periods

\section{Variables}

$v g e_{a, g, s, t}$ production of electricity in area $a$, on technology $g$, season $s$ and time $t$

$v g f_{a, g, s, t}$ usage of fuel in area $a$, on existing technology $g$, season $s$ and time $t$

$v g f n_{a, g, s, t}$ usage of fuel in area $a$, on new technology $g$, season $s$ and time $t$

$v g h_{a, g, s, t}$ production of heat in area $a$, on technology $g$, season $s$ and time $t$

\section{Parameters}

$C_{g}^{v}$ Amount of electricity generation reduction per unit of heat generated on technology $g$

$d e_{a, s, t}$ The demand of electricity in area $a$ in season $s$ and time $t$

$G M I N 2 F_{c, f, f^{\prime}}$ Common target in country $c$ for fuel type $f$ and $f^{\prime}$

$c_{a, g}$ Capacity of technology $g$ in area $a$ cost $_{g}$ The cost of producing electricity on technology $g$

fuel $(g)$ Fuel type used on technology $g$ $v g e_{g}^{\max }$ The maximum electricity production on technology type $g$

$v g e_{g}^{\min }$ The minimum electricity production on technology type $g$ 


\section{Tables}

\begin{tabular}{l|cc}
\hline Regulation type & 2015 & 2025 \\
\hline \hline Electricity feed-in tariff, CHP - raw biogas & 16.8 Eurocent/kWh & 12.8 Eurocent/kWh \\
Avoided fuel tax on heat, CHP - raw biogas & 3.1 Eurocent/kWh & 3.1 Eurocent/kWh \\
Biogas feed-in premium, biomethane & 16.8 Euro/GJ & 12.8 Euro/GJ \\
\hline
\end{tabular}

Table 1: Direct and indirect support for biogas, in 2015-prices

\begin{tabular}{lccc}
\hline & Type of price & Price, $€ / \mathrm{GJ}$ & $\mathrm{CO}_{2}$-emissions, kg/GJ \\
\hline \hline Fossil Fuels & $\begin{array}{c}\text { Market prices [31] } \\
\text { Biomasses }\end{array}$ & $\begin{array}{c}\text { Predicted avg. prices } \\
\text { Combedicted avg. prices }\end{array}$ & $\begin{array}{c}\text { Standard figures [31] } \\
\text { Avg. figures calculated on } \\
\text { expected usage [30] }\end{array}$ \\
\hline Raw biogas & Cost calculated [31] $[27]$ & 10.2 & $-77[30]$ \\
Biomethane & Cost calculated [27] & 12.1 & $-77[30]$ \\
Natural gas & Market prices & $6.7[31]$ & $56.8[31]$ \\
Straw & Comb. of market and cost & $6.3[31]$ & $11[29]$ \\
& prices & & \\
\hline
\end{tabular}

Table 2: Fuel data

\begin{tabular}{lccc}
\hline & Actual, Energy system, 2015 & Forecasted, Energy System, & Target or Maximum \\
& & 2025 & \\
\hline \hline Biogas & $4.3 \mathrm{PJ}$ & 3.8 PJ & Target \\
Natural gas & 34.5 PJ & 28 PJ & Maximum \\
\hline
\end{tabular}

Table 3: Forecasts and targets, [17]

\begin{tabular}{lcccc}
\hline & \multicolumn{2}{c}{ Existing capacity } & \multicolumn{2}{c}{ Efficiency } \\
\cline { 2 - 4 } & Raw biogas & Combination technology & Raw biogas & Combination technology \\
\hline \hline Heat Only & $19 \mathrm{MW}$ & $3,161 \mathrm{MW}$ & $80.7 \%$ & $95.6 \%$ \\
CHP & $107 \mathrm{MW}$ & $934 \mathrm{MW}$ & $89.9 \%$ & $90.5 \%$ \\
Electricity Only & $0.3 \mathrm{MW}$ & $0.8 \mathrm{MW}$ & $31.7 \%$ & $44.0 \%$ \\
\hline
\end{tabular}

Table 4: Technology data, $[36,37]$

\begin{tabular}{lccc}
\hline Scenario & Target & CO2-cost level & CO2-cost, $€ /$ ton \\
\hline \hline Base & - & Average & 15.3 \\
Target & + & Average & 15.3 \\
\hline CO2High/Base & - & High & 23.1 \\
CO2High/Target & + & High & 23.1 \\
CO2Low/Target & + & Low & 7.5 \\
\hline
\end{tabular}

Table 5: Settings for the scenarios 


\begin{tabular}{lcccc}
\hline Scenario & CO2-cost & Natural gas & Biomethane & Biogas \\
\hline \hline CO2High/Target & 23.1 & 8.0 & 11.8 & 9.7 \\
CO2Dice/Target & 30.3 & 8.4 & 11.3 & 9.2 \\
CO2Bergh/Target & 99.2 & 12.4 & 6.0 & 3.8 \\
\hline
\end{tabular}

Table 6: $\mathrm{CO}_{2}$-costs for the high $\mathrm{CO}_{2}$-cost scenarios, $€ 2015 /$ ton

\begin{tabular}{lccccc}
\hline & Base & Target & CO2High/Base & CO2High/Target & CO2Low/Target \\
\hline \hline OBJ, M€ & 35,798 & 35,804 & 37,928 & 37,931 & 33,385 \\
$\Delta$ OBJ, M $€$ & - & 6 & 2,130 & 2,133 & $-2,414$ \\
MTE, $€$ GJ & - & 2.22 & - & 1.23 & 3.36 \\
$\mathrm{CO}_{2}$-total, MT & 296.7 & 296.3 & 253.1 & 252.7 & 320.7 \\
$\mathrm{CO}_{2}$-DK, MT & 8.0 & 7.8 & 8.1 & 7.8 & 7.8 \\
\hline
\end{tabular}

Table 7: Results of the five scenarios. OBJ is the objective function value, $\Delta$ OBJ is the change in the objective function from the Base scenario, MTE is the marginal value of the biogas target constraint (Equation 7), and $\mathrm{CO}_{2}$-total and $\mathrm{CO}_{2}$-DK are the $\mathrm{CO}_{2}$-emissions from the total energy system and for the Danish energy system

\begin{tabular}{lccccc}
\hline & Base & Target & CO2High/Base & CO2High/Target & CO2Low/Target \\
\hline \hline Biogas usage, GJ & 485,731 & $2,083,290$ & 776,758 & $2,517,432$ & $1,964,166$ \\
Biomethane usage, GJ & - & $1,716,710$ & - & $1,282,568$ & $1,835,834$ \\
Natural gas usage, GJ & $28,000,000$ & $28,000,000$ & $28,000,000$ & $28,000,000$ & $28,000,000$ \\
\hline BM-COMB & $0 \%$ & $5.8 \%$ & $0 \%$ & $4.5 \%$ & $6.1 \%$ \\
\%-COMB & $11.7 \%$ & $12.1 \%$ & $11.0 \%$ & $11.3 \%$ & $11.8 \%$ \\
New COMB-capacity, MW & 525 & 568 & 352 & 389 & 735 \\
\hline
\end{tabular}

Table 8: Fuel usage, basic results. BM-COMB represents the percentage usage of biomethane in the combination technologies and \%-COMB represents the percentage that the combination technologies are used

\begin{tabular}{lccc}
\hline & CO2High/Target & CO2Dice/Target & CO2Bergh/Target \\
\hline \hline OBJ, M€ & 37,931 & 39,685 & 36,437 \\
MTE, $€ /$ GJ & 1.23 & 0.13 & - \\
\%-COMB & $11.3 \%$ & $10.7 \%$ & $44.3 \%$ \\
New COMB-capacity, MW & 389 & 352 & 3,443 \\
$\mathrm{CO}_{2}$-total, MT & 252.7 & 232.4 & -178.4 \\
$\mathrm{CO}_{2}$-DK, MT & 7.8 & 7.7 & -13.3 \\
\hline
\end{tabular}

Table 9: Results of the high $\mathrm{CO}_{2}$-scenarios. MTE is the marginal value of the biogas target constraint (Equation 7) and \%-COMB represents the percentage that the combination technologies are used. The capacity installed on the combination technnologies are given by New COMB-capacity, and the $\mathrm{CO}_{2}$-emissions for the system and for Denmark is given by $\mathrm{CO}_{2}$-total and $\mathrm{CO}_{2}$-DK. 


\section{Figures}

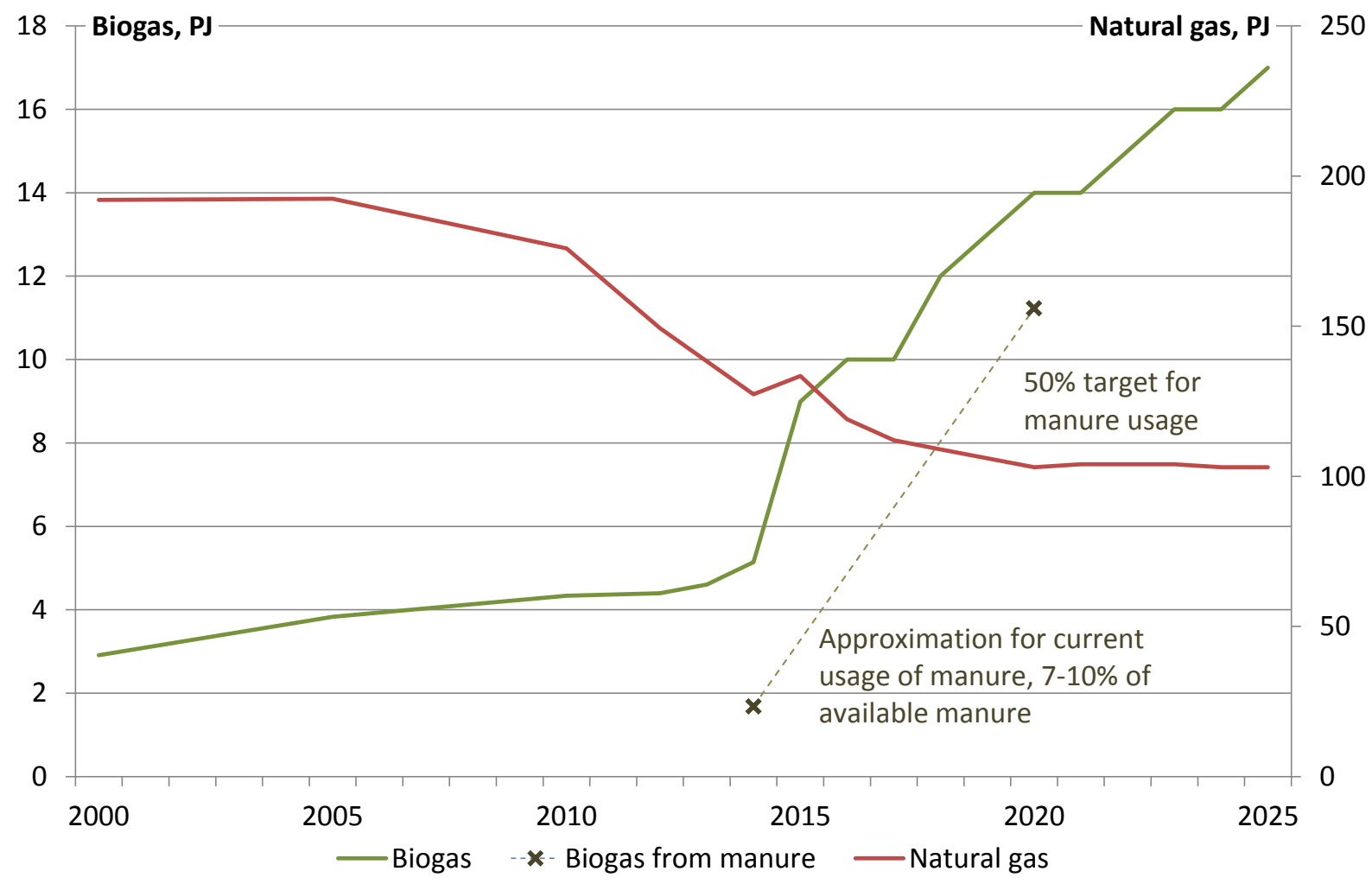

Figure 1: Biogas target shown on the left $\mathrm{y}$-axis compared to the natural gas demand on the right y-axis 


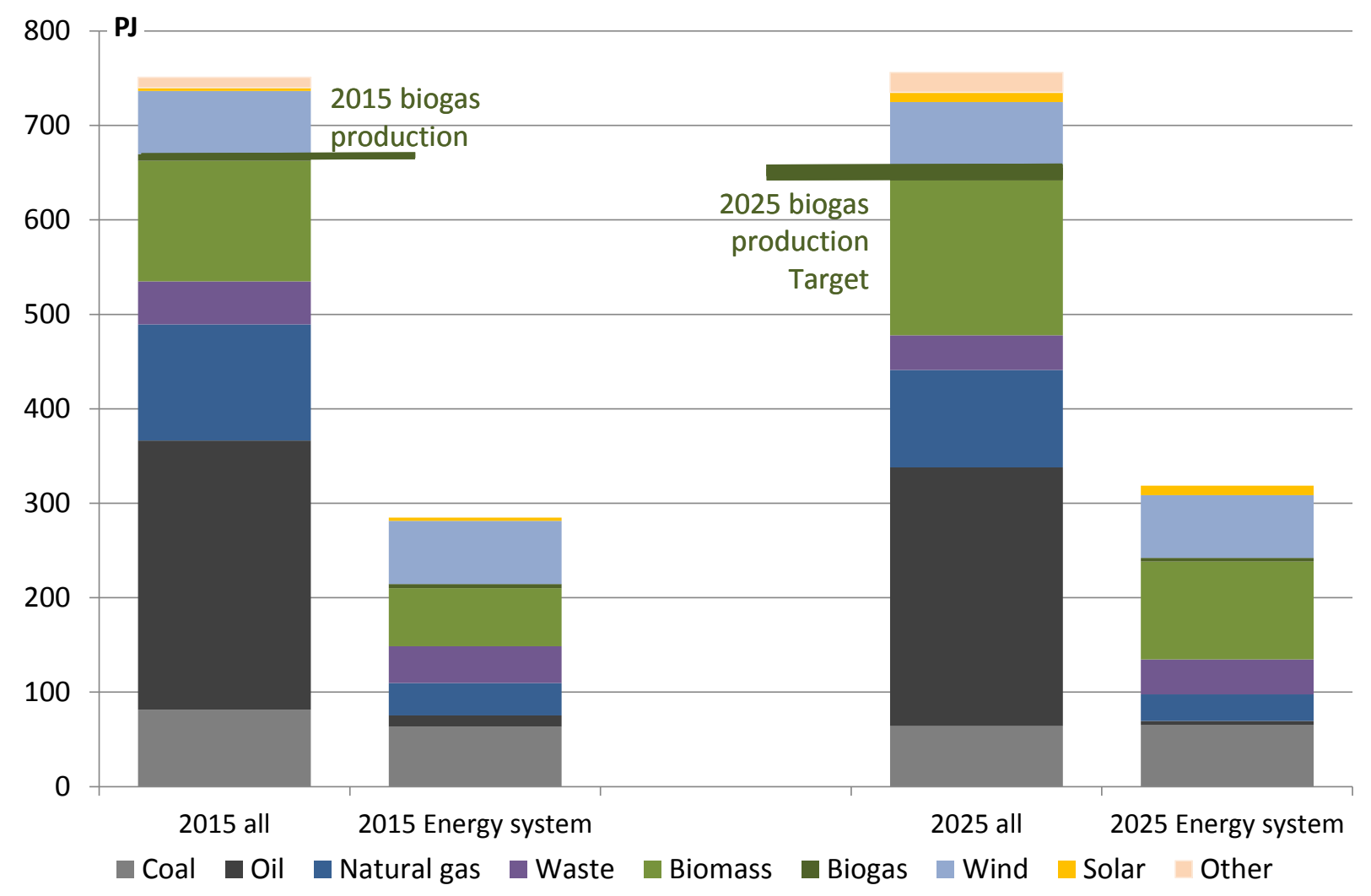

Figure 2: Danish fuel consumption 


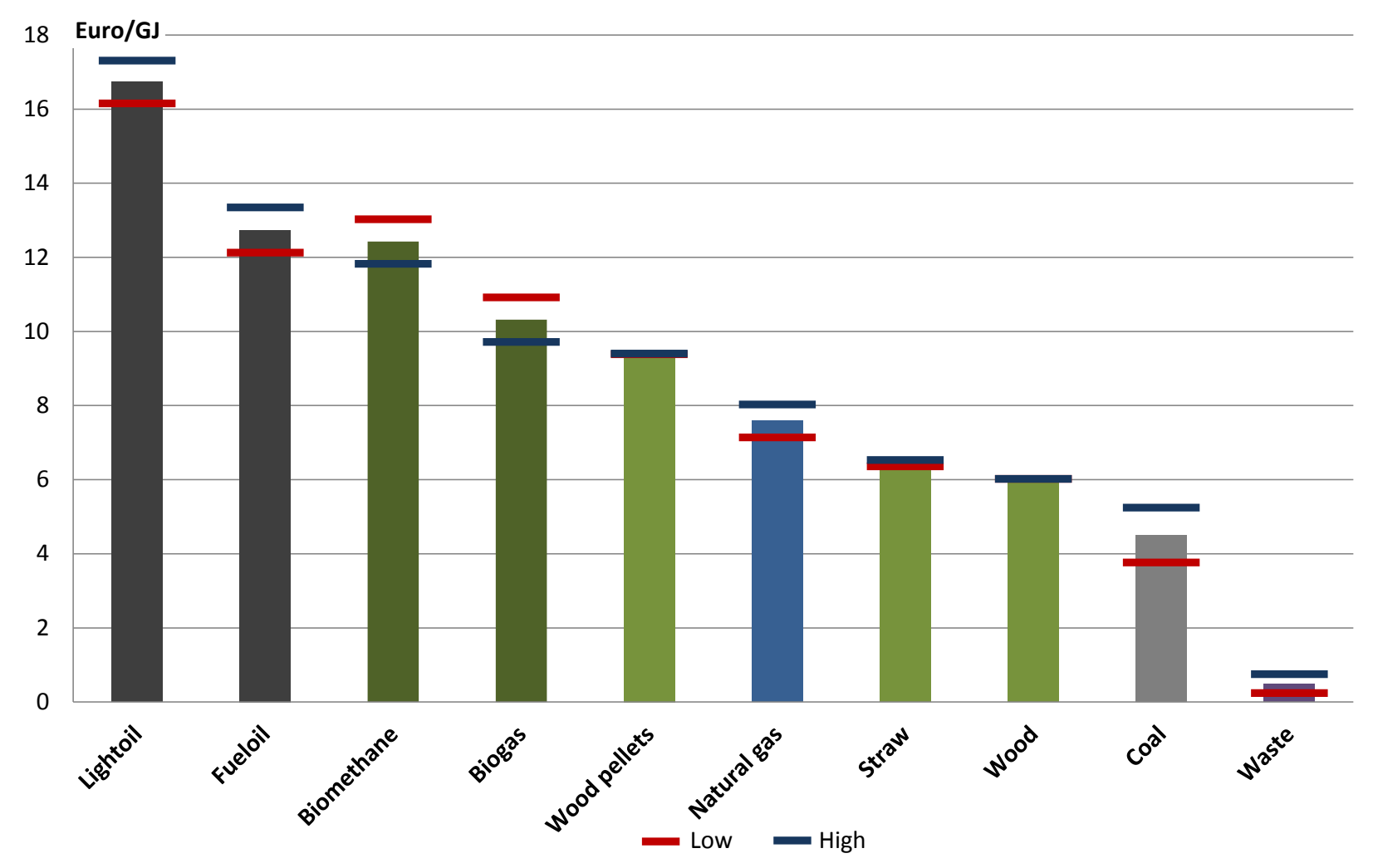

Figure 3: Fuel costs, when the $\mathrm{CO}_{2}$-cost is added; for average, low, and high $\mathrm{CO}_{2}$-costs 


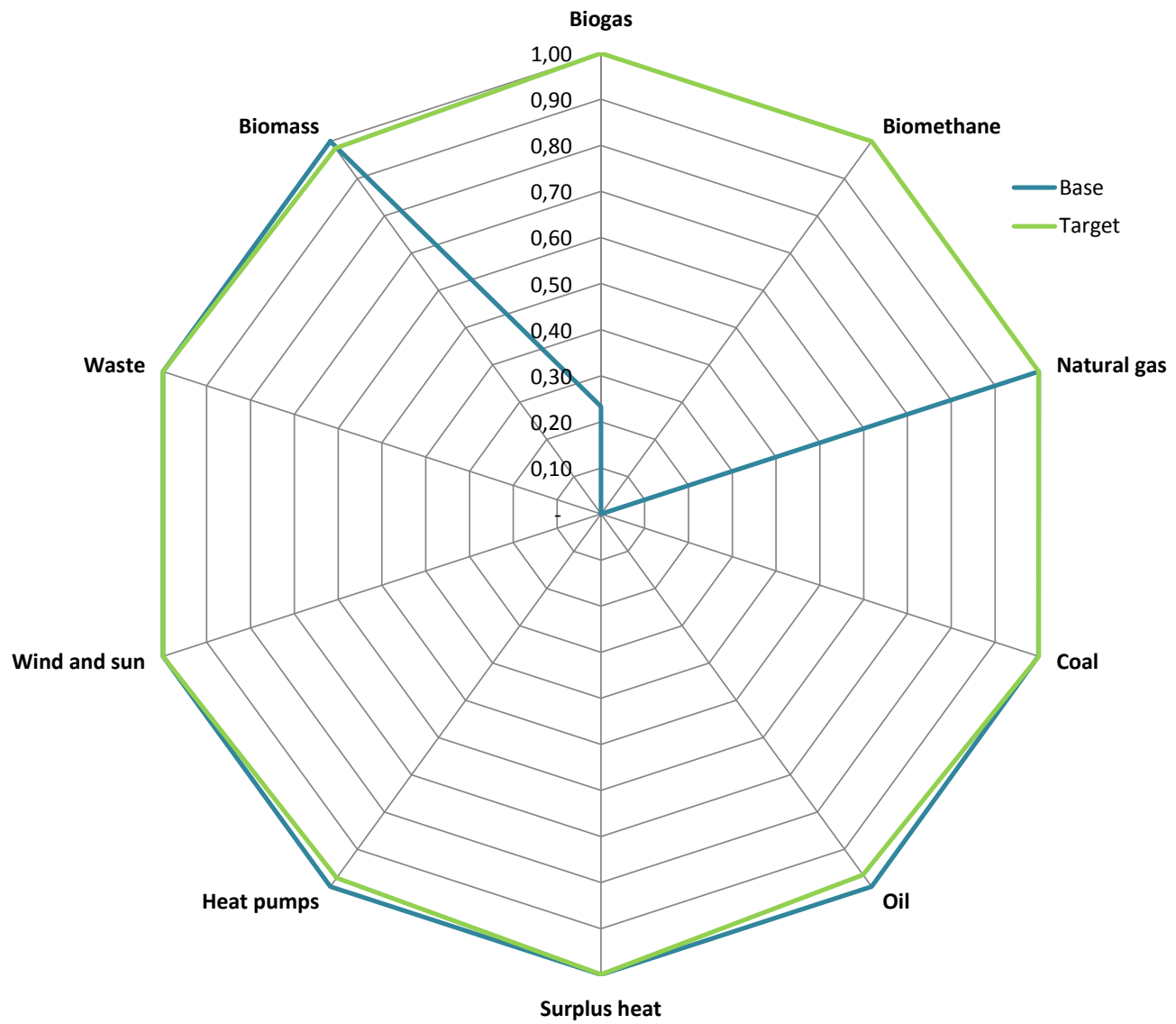

Figure 4: Normalised fuel usage for Denmark in the base and target scenario 


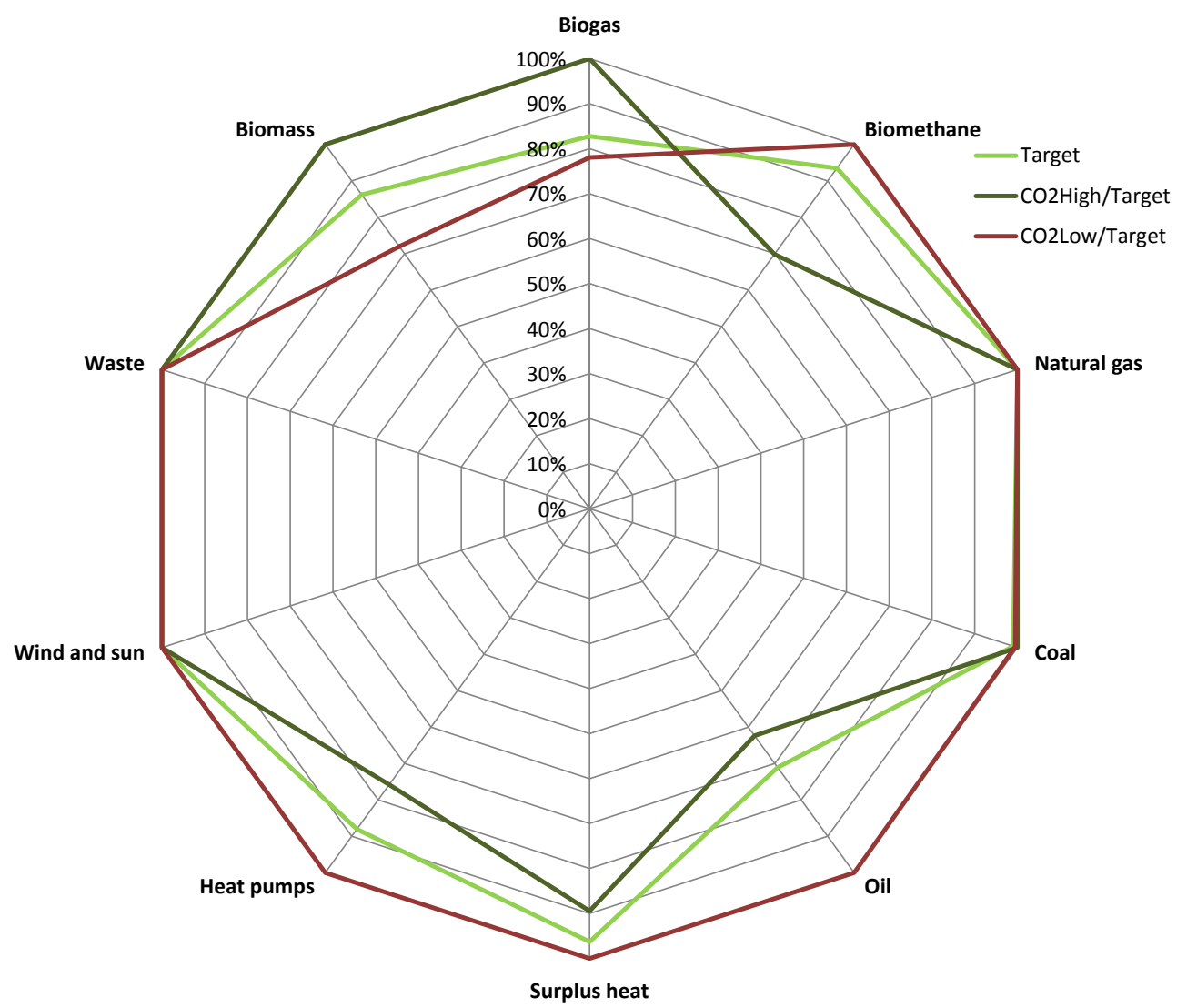

Figure 5: Normalised fuel usage for Denmark in the target scenarios 


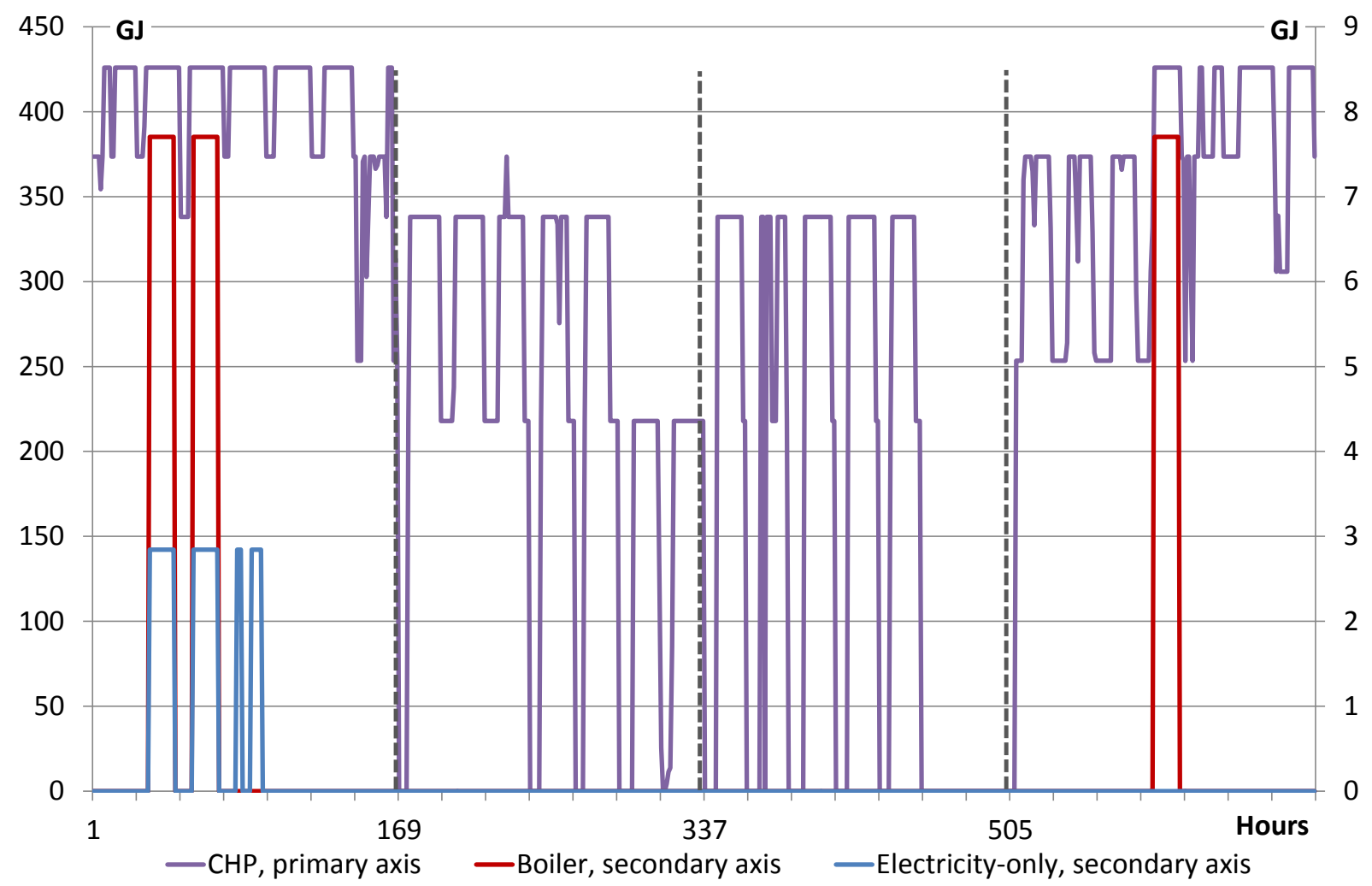

Figure 6: Usage distribution of raw biogas in the $\mathrm{CO}_{2} \mathrm{High} /$ Target scenario 


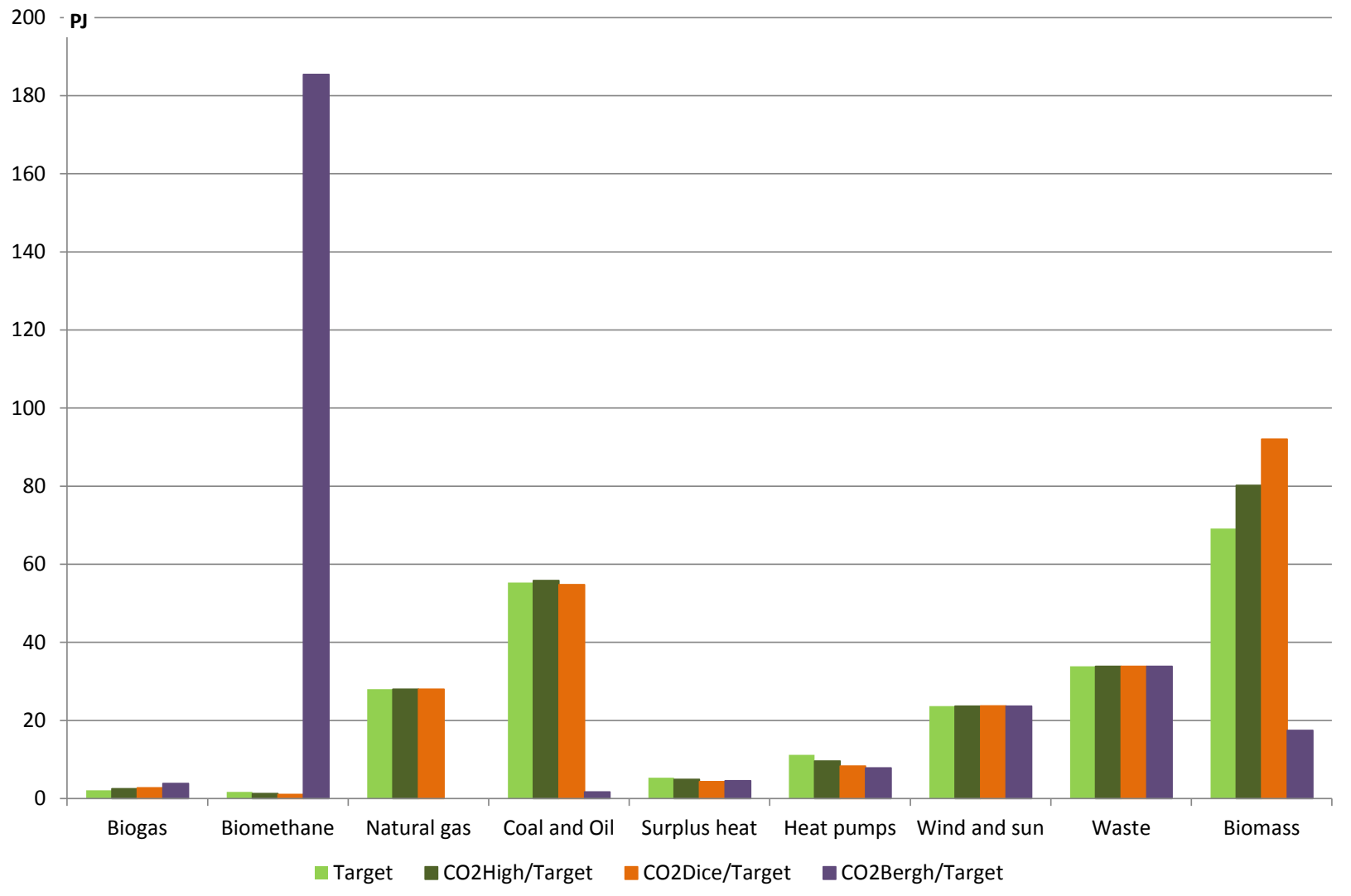

Figure 7: Fuel usage in Denmark for the scenarios with high $\mathrm{CO}_{2}$-cost 